\title{
Morphological and Physiological Responses of Ornamental Grasses to Saline Water Irrigation
}

\author{
Haifeng Xing \\ College of Grassland Resources and Environment, Inner Mongolia \\ Agricultural University, Hohhot, Inner Mongolia 010010, China
}

Julie Hershkowitz, Asmita Paudel, Youping Sun, and Ji Jhong Chen Department of Plants, Soils, and Climate, Utah State University, 4820 Old Main Hill, Logan, UT 84322

\section{Xin Dai \\ Utah Agricultural Experiment Station, Utah State University, 4810 Old Main Hill, Logan, UT 84322}

\section{Matthew Chappell \\ Department of Horticulture, University of Georgia, 326 Hoke Smith Building, Athens, GA 30602}

Additional index words. Acorus gramineus, Andropogon ternarius, Calamagrostis $\times$ acutiflora, Carex morrowii, Festuca glauca, gas exchange, landscape plant, Sporobolus heterolepis, visual quality

Abstract. Reclaimed water provides a reliable and economical alternative source of irrigation water for landscape use but may have elevated levels of salts that are detrimental to sensitive landscape plants. Landscape professionals must use salttolerant plants in regions where reclaimed water is used. Ornamental grasses are commonly used as landscape plants in the Intermountain West of the United States due to low maintenance input, drought tolerance, and unique texture. Six ornamental grass species, including Acorus gramineus (Japanese rush), Andropogon ternarius (silver bluestem), Calamagrostis xacutiflora (feather reed grass), Carex morrowii (Japanese sedge), Festuca glauca (blue fescue), and Sporobolus heterolepis (prairie dropseed), were evaluated for salinity tolerance. Plants were irrigated every 4 days with a fertilizer solution at an electrical conductivity (EC) of $1.2 \mathrm{dS} \cdot \mathrm{m}^{-1}$ (control) or with a saline solution at an EC of $5.0 \mathrm{dS} \cdot \mathrm{m}^{-1}$ (EC 5) or $10.0 \mathrm{dS} \cdot \mathrm{m}^{-1}$ (EC 10). At 47 days, most species in EC 5 exhibited good visual quality with averaged visual scores greater than $4.6(0=$ dead, $5=$ excellent $)$. In EC 10, most $A$. gramineus plants died, but $C$. $\times$ acutiflora, $F$. glauca, and $S$. heterolepis had no foliar salt damage. At 95 days, $C$. $\times$ acutiflora, $F$. glauca, and $S$. heterolepis in EC 5 had good visual quality with averaged visual scores greater than 4.5. Acorus gramineus, $A$. ternarius, and $C$. morrowii showed foliar salt damage with averaged visual scores of 2.7, 3.2, and 3.4, respectively. In EC 10, A. gramineus died, and other grass species exhibited moderate to severe foliar salt damage, except $C$. $\times$ acutiflora, which retained good visual quality. Plant height, leaf area, number of tillers, shoot dry weight, and/or gas exchange parameters also decreased depending on plant species, salinity level, and the duration of exposure to salinity stress. In conclusion, $A$. gramineus was the most salt-sensitive species, whereas $C$. $\times$ acutiflora was the most salt-tolerant species. Festuca glauca and $S$. heterolepis were more tolerant to salinity than $A$. ternarius and $C$. morrowii. Calamagrostis $\times$ acutiflora, $F$. glauca, and $S$. heterolepis appear to be more suitable for landscapes in which reclaimed water is used for irrigation. Plant responses to saline water irrigation in this research could also be applied to landscapes in salt-prone areas and coastal regions with saltwater intrusion into aquifers and landscapes affected by maritime salt spray.

Saline soils affect more than 800 million ha of land worldwide, which equates to more than $6 \%$ of total arable land area (Muchate et al., 2016; Munns, 2005). This trend continues as new fertile and productive soils are heavily cropped and irrigated with highly alkaline irrigation water, a major cause of increasing soil salinity over time (Ghassemi et al., 1995). As competition for and cost of potable water increase in the southern and western United States, reclaimed water has become more common in landscape irrigation. Although reclaimed water contains nutrients essential for plant growth (Niu and Rodriguez, 2006), it also possesses chemicals [e.g., sodium chloride $(\mathrm{NaCl})]$ that accumulate in the soil and can be detrimental to some taxa. The salt content of reclaimed water is typically 2 to 3 times higher than in potable water (Khurram and Miyamoto, 2005; Wu et al., 2001). Salts accumulated in the soil affect the productivity (biomass production) and visual quality of salt-sensitive species (Mane et al., 2011). Saline water decreases water potential, which in turn reduces the ability of plants to uptake water, thereby slowly imposing salinity stress on the plants. The continued use of reclaimed water in landscape irrigation makes it essential and meaningful to assess the salinity tolerance of landscape plants. It is also imperative to select the most salt-tolerant plant species for use in salt-prone areas.

Plant salt tolerance is often evaluated and classified by morphological and physiological characteristics. In response to salinity stress, plants exhibit slower shoot and root growth, smaller leaves, increased foliar injury, and premature leaf senescence (Muchate et al., 2016; Munns 2005). Salinity stress also inhibits photosynthesis, decreases stomatal conductance $\left(g_{\mathrm{S}}\right)$, and causes nutrient deficiencies (Munns and Tester, 2008) that ultimately affect crop productivity (Muchate et al., 2016). Overall plant morphological appearance and physiological response to salinity stress are important considerations when determining salt tolerance of individual taxa (Hasegewa et al., 2000; Munns, 2002).

Some researchers have postulated that ornamental plants are less salt-tolerant than forage or other field crops (Amacher et al., 2000), and cool-season grasses are usually more salt-sensitive than warm-season ones (Schiavon et al., 2012, 2014). However, ornamental grass species and/or cultivars have a wide range of responses to salinity that effect growth and physiological characteristics (Sun and Palmer, 2018; Wang et al., 2019). Most grasses cannot survive in more than 200 to $300 \mathrm{~mm}\left(\approx 14.6\right.$ to $\left.21.9 \mathrm{dS} \cdot \mathrm{m}^{-1}\right) \mathrm{NaCl}$ (Gulzar et al., 2003; Pearen et al., 1997). However, Urochondra setulosa can grow well when irrigated with $600 \mathrm{~mm} \mathrm{NaCl}\left(\approx 43.8 \mathrm{dS} \cdot \mathrm{m}^{-1}\right)$ solution (Gulzar et al., 2003). Amacher et al. (2000) summarized the salt tolerance of nearly 100 species grown in Utah including field crops, forages, vegetables, fruit and nut crops, flowers, and turfgrasses. They classified Poa pratensis (kentucky bluegrass) and Poa annua (annual bluegrass) as salt-sensitive grasses, whereas observations indicated Puccinellia nutkaensis (Nootka alkaligrass), which can thrive at an EC of 9.0 to $12.0 \mathrm{dS} \cdot \mathrm{m}^{-1}$, is a highly tolerant species. Muhlenbergia capillaris (pink muhly grass) can grow when irrigated with $10,000 \mathrm{mg} \cdot \mathrm{L}^{-1} \mathrm{NaCl}\left(\approx 12.5 \mathrm{dS} \cdot \mathrm{m}^{-1}\right)$ solution (LeCompte et al., 2016). Similarly, Wang et al. (2019) reported that Eragrostis spectabilis (purple love grass), Miscanthus sinensis (maiden silvergrass), Panicum virgatum (switchgrass), and Schizachyrium scoparium (little bluestem) performed well even when irrigated with a saline solution at an EC of 10.0 $\mathrm{dS} \cdot \mathrm{m}^{-1}$ for 9 weeks. However, Briza media (quaking grass) is very sensitive to salt, and its morphological characteristics such as shoot dry weight, plant height, and visual quality 
deteriorate at an EC as low as $2.5 \mathrm{dS} \cdot \mathrm{m}^{-1}$ (McKenney et al., 2016).

Cities and suburbs are emphasizing the creation and maintenance of appealing public and private landscapes using ornamental plants. Ornamental grasses are often used in landscapes in Utah and the Intermountain West due to their drought tolerance and low maintenance requirements (Gunnell et al., 2015). Although ornamental grasses have been evaluated for their salinity tolerance, more research-based information is needed to enable landscape professionals to choose the right grass species for regions where reclaimed water is used. Acorus gramineus 'Minimus Aureus', Andropogon ternarius 'Black Mountain', Calamagrostis $\times$ acutiflora 'Karl Foerster', Carex morrowii 'Ice Dance', Festuca glauca 'Elijah Blue', and Sporobolus heterolepis are popular in landscapes in the United States due to low maintenance input, strong drought tolerance, and unique texture and pattern, but their salt tolerance remains largely unknown. The objective of this study was to determine the effect of saline solution irrigation on the growth and physiology of six aforementioned ornamental grasses and to evaluate each species' tolerance to saline conditions.

\section{Materials and Methods}

Plant materials and greenhouse conditions. On 14 June 2019, rooted plugs of six ornamental grasses in 32-cell trays $(5.5 \times 5.5 \times$ $10.5 \mathrm{~cm}$ ) were received from Hoffman Nursery (Rougemont, NC). Plants $(\approx 10 \mathrm{~cm}$ tall) were

Received for publication 12 Jan. 2021. Accepted for publication 26 Mar. 2021.

Published online 27 May 2021

We are grateful for the in-kind support of plant materials from Hoffman Nursery (Rougemont, NC) and valuable comments from anonymous reviewers

This research was supported in part by the U.S Department of Agriculture (USDA) National Institute of Food and Agriculture (NIFA) Hatch project UTA01381 and USDA Specialty Crop Block Grant Program, New Faculty Start-Up Funds from the Office of Research and Graduate Studies, the Center for Water-Efficient Landscaping and the Utah Agricultural Experiment Station (UAES) at Utah State University. It is approved as UAES journal paper number 9458. This research was also supported in part by the Center for Applied Nursery Research, a nonprofit research center located in Dearing, GA. We appreciate the financial support from China Scholarship Council to Haifeng Xing as a visiting scholar at Utah State University, Logan, UT.

The content is solely the responsibility of the authors and does not necessarily represent the official views of the funding agencies. Mention of a trademark, proprietary product, or vendor does not constitute a guarantee or warranty of the product by the USDA or the American Society for Horticultural Science and does not imply its approval to the exclusion of other products or vendors that also may be suitable.

H.X. and Y.S. are the corresponding authors. E-mail: nmgxinghaifeng@126.com or youping.sun@usu.edu. This is an open access article distributed under the CC BY-NC-ND license (https://creativecommons. org/licenses/by-nc-nd/4.0/). placed in a single-gable glass greenhouse at Utah State University (lat. $41^{\circ} 45^{\prime} 28^{\prime \prime} \mathrm{N}$, long. $111^{\circ} 48^{\prime} 47^{\prime \prime} \mathrm{W}$, elevation $1409 \mathrm{~m}$ ) and watered with tap water $\left(\mathrm{EC}=0.31 \mathrm{dS} \cdot \mathrm{m}^{-1} ; \mathrm{pH}=7.3\right)$. During the experiment, greenhouse temperatures were maintained at $25^{\circ} \mathrm{C}$ during the day and $20^{\circ} \mathrm{C}$ at night using a fan-and-pad evaporative cooling system. Light intensities were recorded hourly using a heated silicon chip pyranometer (SP-230; Apogee Instruments, Logan, UT) mounted to a weather station at the Utah Agricultural Experiment Station's Greenville Research Farm (North Logan, UT), $\approx 1000 \mathrm{~m}$ away from the greenhouse. A light transmission rate of $68 \%$ was used when calculating the daily light integral (DLI) inside the greenhouse, and the DLI was $28.8 \pm 10.8$ $\mathrm{mol} \cdot \mathrm{m}^{-2} \cdot \mathrm{d}^{-1}$ (mean $\pm \mathrm{SD}$ ) from 14 June to 12 Nov. 2019. Supplemental lights at an averaged intensity of $337 \pm 55 \mu \mathrm{mol} \cdot \mathrm{m}^{-2} \cdot \mathrm{s}^{-1}$ at plant canopy level were provided using 1000-W high-pressure sodium lamps (Hydrofarm, Petaluma, CA) from 9 Sept. to 12 Nov. 2019 when light intensity inside the greenhouse was less than $544 \mu \mathrm{mol} \cdot \mathrm{m}^{-2} \cdot \mathrm{s}^{-1}$ from 0600 to $2200 \mathrm{HR}$.

On 5 July 2019, plants were potted in 7.6$\mathrm{L}$ injection-molded polypropylene containers (No. 2B Nursery Supplies, Orange, CA) filled with a growing substrate consisting of $75 \%$ peatmoss (Canadian sphagnum peatmoss; Sun Gro Horticulture, Agawam, MA), 25\% vermiculite (Therm-O-Rock West, Chandler, AZ), $0.89 \mathrm{~kg} \cdot \mathrm{m}^{-3}$ gypsum ( $92 \%$ calcium sulfate dihydrate, $21 \%$ calcium, $17 \%$ sulfur, Athletic White Sports Field Marking Gypsum, Western Mining and Minerals, Bakersfield, CA), $1.57 \mathrm{~kg} \cdot \mathrm{m}^{-3}$ dolomitic lime (Lhoist North America, Salinas, CA), and $0.65 \mathrm{~kg} \cdot \mathrm{m}^{-3}$ wetting agent (AquaGro G; Aquatrols, Paulsboro, NJ). On 9 Aug. 2019, plants were pruned to uniform height $(\approx 15$ $\mathrm{cm}$ ), except $A$. gramineus, a nearly stemless groundcover that averaged $9.4 \mathrm{~cm}$ tall.

Treatments. A nutrient solution (control) at an EC of $1.2 \mathrm{dS} \cdot \mathrm{m}^{-1}$ with a nitrogen concentration of $120 \mathrm{mg} \cdot \mathrm{L}^{-1}$ was prepared by adding 0.8 $\mathrm{g} \cdot \mathrm{L}^{-1}$ water-soluble fertilizer $15 \mathrm{~N}-2.2 \mathrm{P}-12.5 \mathrm{~K}$ (Peters 15-5-15 Cal-Mag Special; Scotts, Marysville, $\mathrm{OH}$ ) to tap water. Sodium chloride (NaCl; Fisher Scientific, Waltham, MA) and dihydrate calcium chloride $\left(\mathrm{CaCl}_{2} \cdot 2 \mathrm{H}_{2} \mathrm{O}\right.$; Hi Valley Chemical, Centerville, UT) were added to the nutrient solution to create two saline solution treatments at an EC of 5.0 or $10.0 \mathrm{dS} \cdot \mathrm{m}^{-1}$ (Table 1). The $\mathrm{pH}$ of the nutrient and saline solutions was maintained at $6.42 \pm 0.05$ using 1 $\mathrm{mol} \cdot \mathrm{L}^{-1}$ nitric acid. From 9 Aug. to $9 \mathrm{Nov}$. 2019, grasses were irrigated every $4 \mathrm{~d}$ with 1.5 $\mathrm{L}$ of nutrient solution or saline solution, resulting in a leaching fraction of $50 \pm 10 \%$. After each irrigation event, the EC of the leachate generated from the pour-through method described by Gibson et al. (2007) was determined using an EC meter (LAQUA Twin; Horiba, Kyoto, Japan). One plant per treatment per species was chosen for measurement, and EC values were averaged across six species at each irrigation event.

Plant harvest and data collection. Grasses were harvested twice during the experiment. The first harvest was done for all six grass species with five plants per treatment per species destructively harvested on 25 Sept. 2019 (47 d after the initiation of treatments, 12 irrigation events). The second harvest of the remaining five plants was conducted on 12 Nov. 2019 (95 d after the initiation of treatments, 24 irrigation events) for all grass species with the exception of $A$. gramineus, which was harvested on 10 Oct. 2019 (62 d after the initiation of treatments, 16 irrigation events) because all plants died at an EC of $10.0 \mathrm{dS} \cdot \mathrm{m}^{-1}$.

Relative chlorophyll content was recorded for all grass species using a soil plant analysis development (SPAD) chlorophyll meter (SPAD-502; Minolta Camera Co., Osaka, Japan) before harvest. Five mature leaves from each plant were measured, and the averaged SPAD value was recorded. Ten and five plants were recorded for SPAD reading at the first and second harvest, respectively. Leaf net photosynthetic rate $\left(\mathrm{P}_{\mathrm{n}}\right)$, $g_{\mathrm{S}}$, transpiration rate $(E)$, and water use efficiency (WUE) of grasses were measured $1 \mathrm{~d}$ before each harvest date using a portable photosynthesis system with an automatic universal PLC3 universal leaf cuvette (CIRAS-3; PP Systems, Amesbury, MA). Fully expanded leaves of five plants in each treatment were used for the measurement. Environmental conditions in the cuvette were controlled at $25^{\circ} \mathrm{C}, 1000 \mu \mathrm{mol} \cdot \mathrm{m}^{-2} \cdot \mathrm{s}^{-1}$ photosynthetic photon flux and $400 \mu \mathrm{mol} \cdot \mathrm{mol}^{-1} \mathrm{CO}_{2}$. Data were recorded once the environmental conditions and gas exchange parameters in the cuvette became stable. All plants were well watered before measurement to avoid water stress. Measurements were taken on sunny days generally between 1100 and $1400 \mathrm{HR}$. Relative chlorophyll content and gas exchange were not taken for $A$. gramineus and $F$. glauca because of their narrow leaves.

Visual score was assigned to each plant at each harvest date by giving a score from 0 to 5 where, $0=$ dead; $1=$ severe foliar salt damage (more than $90 \%$ leaves with burn and necrosis at the top part of leaf blade); $2=$ moderate foliar salt damage (50\% to $90 \%) ; 3=$ slight foliar salt damage (less than $50 \%$ ); 4 = good quality with minimal foliar salt damage (less than $10 \%$ ); and $5=$ excellent without foliar salt damage (Sun et al., 2015). Plant size was not considered when assigning the visual score. At each harvest date, plant height (centimeters) was recorded from the surface of growing media to the tip of the tallest leaf. Ten and five plants were recorded for visual score and plant height at the first and second harvest, respectively. The number of tillers was counted, and leaf area (square centimeters) was measured using a leaf area meter (LI-3100; LI-COR Biosciences, Lincoln, NE). In addition, shoot dry weight was measured after grasses were dried in an oven at $80^{\circ} \mathrm{C}$ for $5 \mathrm{~d}$. The final substrate EC (ECe) was determined using a saturated soil paste technique (Gavlak et al., 1994) with some modification (Sun et al., 2020a). At each harvest date, three containers per treatment per species were randomly selected and left for drying in the greenhouse for at least 2 weeks, 
Table 1. Mineral contents, sodium absorption ratio (SAR), and electrical conductivity (EC) of nutrient solution and saline solution used in the study.

\begin{tabular}{lccc} 
& & \multicolumn{2}{c}{ Saline solution $^{\mathrm{x}}$} \\
\cline { 3 - 4 } $\mathrm{Item}^{\mathrm{z}}$ & Nutrient solution & $5.0 \mathrm{dS} \cdot \mathrm{m}^{-1}$ & $10.0 \mathrm{dS} \cdot \mathrm{m}^{-1}$ \\
\hline $\mathrm{Ca}^{2+}\left(\mathrm{mg} \cdot \mathrm{L}^{-1}\right)$ & 80.6 & 371.2 & 897.3 \\
$\mathrm{Mg}^{2+}\left(\mathrm{mg} \cdot \mathrm{L}^{-1}\right)$ & 29.6 & 27.3 & 27.2 \\
$\mathrm{Na}^{+}\left(\mathrm{mg} \cdot \mathrm{L}^{-1}\right)$ & 1.6 & 322.2 & 773.2 \\
$\mathrm{SO}_{4}{ }^{2-}\left(\mathrm{mg} \cdot \mathrm{L}^{-1}\right)$ & 9.8 & 10.6 & 11.8 \\
$\mathrm{Cl}^{-1}\left(\mathrm{mg} \cdot \mathrm{L}^{-1}\right)$ & 1.5 & 1340 & 3260 \\
$\mathrm{~B}\left(\mathrm{mg} \cdot \mathrm{L}^{-1}\right)$ & 0.2 & 0.18 & 0.18 \\
$\mathrm{SAR}$ & 0.04 & 4.34 & 6.93 \\
$\mathrm{Adjusted} \mathrm{SAR}$ & 0.08 & 7.97 & 17.5 \\
$\mathrm{EC}\left(\mathrm{dS} \cdot \mathrm{m}^{-1}\right)$ & $1.21 \pm 0.05$ & $5.04 \pm 0.04$ & $10.2 \pm 0.05$ \\
\hline
\end{tabular}

${ }^{\mathrm{z}}$ Calcium $\left(\mathrm{Ca}^{2+}\right)$, magnesium $\left(\mathrm{Mg}^{2+}\right)$, sodium $\left(\mathrm{Na}^{+}\right)$, sulfate $\left(\mathrm{SO}_{4}^{2-}\right)$, chloride $\left(\mathrm{Cl}^{-}\right)$, and boron (B) ions.

${ }^{\mathrm{y}}$ Water-soluble fertilizer $15 \mathrm{~N}-2.2 \mathrm{P}-12.5 \mathrm{~K}$ (Peter Excel $15-5-15$ Cal-Mag Special) at $0.8 \mathrm{~g} \cdot \mathrm{L}^{-1}$ was added to tap water to make the nutrient solution at an EC of $1.2 \mathrm{dS} \cdot \mathrm{m}^{-1}$.

${ }^{\mathrm{x}}$ Sodium chloride $(\mathrm{NaCl})$ and dihydrate calcium chloride $\left(\mathrm{CaCl}_{2} \cdot 2 \mathrm{H}_{2} \mathrm{O}\right)$ were used to prepare saline solution. $\mathrm{NaCl}$ at $0.92 \mathrm{~g} \cdot \mathrm{L}^{-1}$ and $\mathrm{CaCl}_{2} \cdot 2 \mathrm{H}_{2} \mathrm{O}$ at $1.17 \mathrm{~g} \cdot \mathrm{L}^{-1}$ were added to the nutrient solution to make the saline solution at an $\mathrm{EC}$ of $5.0 \mathrm{dS} \cdot \mathrm{m}^{-1}$, whereas $2.27 \mathrm{~g} \cdot \mathrm{L}^{-1} \mathrm{NaCl}$ and $2.88 \mathrm{~g} \cdot \mathrm{L}^{-1} \mathrm{CaCl}_{2} \cdot 2 \mathrm{H}_{2} \mathrm{O}$ were added to make the saline solution at an EC of $10.0 \mathrm{dS} \cdot \mathrm{m}^{-1}$.

Table 2. Visual score of six ornamental grass species irrigated with a nutrient solution [electrical conductivity $(\mathrm{EC})=1.2 \mathrm{dS} \cdot \mathrm{m}^{-1}$; control] or a saline solution $\left[\mathrm{EC}=5.0 \mathrm{dS} \cdot \mathrm{m}^{-1}\right.$ (EC 5) or 10.0 $\left.\mathrm{dS} \cdot \mathrm{m}^{-1}(\mathrm{EC} 10)\right]$ in a greenhouse. ${ }^{\mathrm{z}}$

\begin{tabular}{|c|c|c|c|c|c|c|}
\hline \multirow[b]{3}{*}{ Таха } & \multicolumn{6}{|c|}{ Visual score ${ }^{\mathrm{y}}$} \\
\hline & \multicolumn{3}{|c|}{ First harvest $(\mathrm{n}=10)$} & \multicolumn{3}{|c|}{ Second harvest $(\mathrm{n}=5)$} \\
\hline & Control & EC 5 & EC 10 & Control & EC 5 & EC 10 \\
\hline$\overline{\text { Acorus gramineus }}$ & $4.8 \mathrm{a}^{\mathrm{x}} \mathrm{A}^{\mathrm{w}}$ & $2.9 \mathrm{bC}$ & $0.3 \mathrm{cD}$ & $4.7 \mathrm{a}$ & $2.7 \mathrm{~b}$ & $0 \mathrm{c}$ \\
\hline Andropogon ternarius & $4.9 \mathrm{aA}$ & $4.6 \mathrm{aA}$ & $3.7 \mathrm{bB}$ & $3 \mathrm{aB}$ & $3.2 \mathrm{aB}$ & $2.7 \mathrm{aB}$ \\
\hline Calamagrostis $\times$ acutiflora & $5 \mathrm{aA}$ & $5 \mathrm{aA}$ & $5 \mathrm{aA}$ & $5 \mathrm{aA}$ & $5 \mathrm{aA}$ & $5 \mathrm{aA}$ \\
\hline Carex morrowii & $4 \mathrm{aB}$ & $3.4 \mathrm{bB}$ & $2.9 \mathrm{cC}$ & $3.8 \mathrm{aB}$ & $3.4 \mathrm{aB}$ & $1.7 \mathrm{bC}$ \\
\hline Festuca glauca & $5 \mathrm{aA}$ & $5 \mathrm{aA}$ & $5 \mathrm{aA}$ & $5 \mathrm{aA}$ & $4.5 \mathrm{aA}$ & $3.2 \mathrm{bB}$ \\
\hline Sporobolus heterolepis & $5 \mathrm{aA}$ & $5 \mathrm{aA}$ & $5 \mathrm{aA}$ & $5 \mathrm{aA}$ & $4.9 \mathrm{aA}$ & $3.3 \mathrm{bB}$ \\
\hline
\end{tabular}

${ }^{\mathrm{z}}$ Grasses were harvested at $47 \mathrm{~d}$ (12 irrigation events, first harvest) and $95 \mathrm{~d}$ (24 irrigation events, second harvest) after the initiation of treatments except $A$. gramineus that was harvested at $62 \mathrm{~d}(16$ irrigation events, second harvest) after the initiation of treatments because $A$. gramineus was dead when irrigated with saline solution at an EC of $10.0 \mathrm{dS} \cdot \mathrm{m}^{-1}$.

${ }^{y_{0}}=$ dead; 1 = severe foliar salt damage (more than $90 \%$ leaves with burn and necrosis); $2=$ moderate foliar salt damage $(50 \%$ to $90 \%) ; 3=$ slight foliar salt damage (less than $50 \%$ ); 4 = good quality with minimal foliar salt damage (less than $10 \%$ ); and $5=$ excellent without foliar salt damage (Sun et al., 2015).

${ }^{\mathrm{x}}$ Means with the same lowercase letters within a row and harvest date are not significantly different among treatments by Tukey's method for multiplicity at $\alpha=0.05$.

${ }^{\mathrm{w}}$ Means with the same uppercase letters within a harvest date and column are not significantly different among species by Tukey's method for multiplicity at $\alpha=0.05$. A. gramineus at the second harvest date is excluded for means separation.

and the top substrate $(\approx 2$ to $3 \mathrm{~cm})$ from the pot was collected for soil extraction.

Experimental design and data analyses. The experiment was conducted using a randomized complete block design with 10 blocks. There were 18 plants in each block (six species and three treatments). Although there were significant interactions between grass species and salinity levels, an analysis of variance was conducted separately for individual species due to various plant growth habits. Visual score was considered as multinomial data, whereas tiller number as negative binomial data. The most appropriate transformation $(\log )$ of data were also conducted for all parameters before statistical analyses. Means separation among treatments (or species for visual score) was adjusted using Tukey's of $5.0 \mathrm{dS} \cdot \mathrm{m}^{-1}$ but had slight to moderate foliar damage with a visual score of 3.7 and 2.9, respectively, when irrigated with saline solution at an EC of $10.0 \mathrm{dS} \cdot \mathrm{m}^{-1}$. No foliar salt damage was observed on $C$. ×acutiflora, $F$. glauca and $S$. heterolepis plants when irrigated with saline solutions at an EC of 5.0 or $10.0 \mathrm{dS} \cdot \mathrm{m}^{-1}$.

All A. gramineus plants died when irrigated with saline solution at an EC of 10.0 $\mathrm{dS} \cdot \mathrm{m}^{-1}$ for $62 \mathrm{~d}$ (16 irrigation events) (Table 2). At an EC of $5.0 \mathrm{dS} \cdot \mathrm{m}^{-1}, A$. gramineus had moderate foliar salt damage with a visual score of 2.7. Therefore, A. gramineus plants were harvested earlier than anticipated. At the second harvest, A. ternarius and C. morrowii exhibited slight foliar salt damage with visual scores ranging from 3.0 to 4.0 when irrigated with saline solution at an EC of 5.0 $\mathrm{dS} \cdot \mathrm{m}^{-1}$ (Table 2). Moderate foliar salt damage was observed on $A$. ternarius and $C$. morrowii plants with a visual score of 2.7 and 1.7 , respectively, when they were irrigated with saline solution at an EC of $10.0 \mathrm{dS} \cdot \mathrm{m}^{-1}$. Andropogon ternarius and C. morrowii plants in the control also exhibited symptoms similar to salt damage with a visual score of 3.0 and 3.8, respectively. However, this may not have been a salt response because A. ternarius blooms in the fall, which causes deterioration of foliage (Hoffman Nursery, 2020). Additionally, C. morrowii is not an evergreen near the northern edge of its growing range (Missouri Botanical Garden, 2020) and was likely entering fall dormancy at the end of the trial, despite the use of supplemental lights in this study. Calamagrostis $\times$ acutiflora did not exhibit any foliar salt damage when irrigated with saline solution at an EC of 5.0 or 10.0 $\mathrm{dS} \cdot \mathrm{m}^{-1}$. Festuca glauca and $\mathrm{S}$. heterolepis had slight foliar salt damage with a visual score of 3.2 and 3.3, respectively, when irrigated with saline solution at an EC of 10.0 $\mathrm{dS} \cdot \mathrm{m}^{-1}$, and minimal salt damage was observed on plants irrigated with saline solution at an EC of $5.0 \mathrm{dS} \cdot \mathrm{m}^{-1}$.

Salinity is known to cause plant foliar damage such as leaf burn, necrosis, and premature discoloration (Sun and Palmer, 2018; Sun et al., 2020a, 2020b). In this study, salinity levels in the leachate increased over time with the irrigation of saline solution (Fig. 1). The average leachate EC of plants irrigated with nutrient solution at an $\mathrm{EC}$ of $1.2 \mathrm{dS} \cdot \mathrm{m}^{-1}$ increased from 0.96 to $2.34 \mathrm{dS} \cdot \mathrm{m}^{-1}$. When plants were irrigated with saline solution at ECs of 5.0 or 10.0 $\mathrm{dS} \cdot \mathrm{m}^{-1}$, the average leachate EC values increased from 1.87 to $7.95 \mathrm{dS} \cdot \mathrm{m}^{-1}$ and from 3.92 to $14.01 \mathrm{dS} \cdot \mathrm{m}^{-1}$, respectively. These results were further confirmed using a saturated soil paste technique at both harvest dates $(P<0.0001$; Fig. 2$)$. Compared with the control, substrate ECe in the treatment of 5.0 or $10.0 \mathrm{dS} \cdot \mathrm{m}^{-1}$, collected at the first harvest date, increased by $\approx 2$ and 3 times, respectively. At the second harvest, substrate ECe in the treatment of 5.0 or 10.0 $\mathrm{dS} \cdot \mathrm{m}^{-1}$ were 3 and 4 times greater than that in the control, respectively. The leachate and substrate EC values obtained in the 


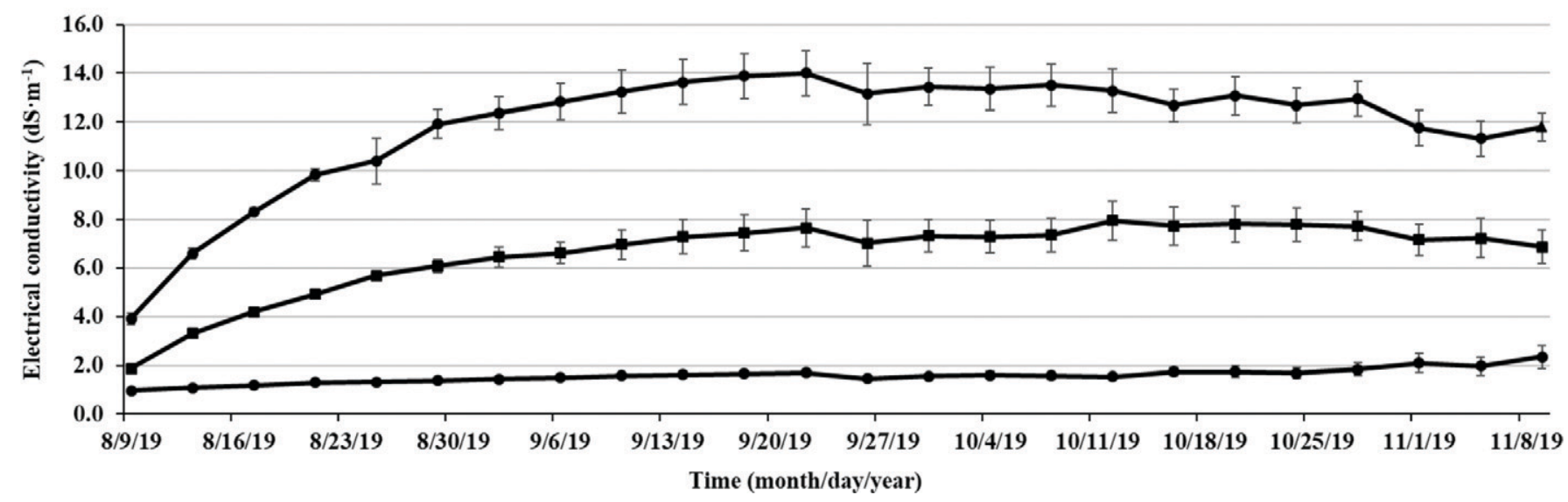

Fig. 1. Electrical conductivity (EC) of leachate solution collected after irrigating ornamental grasses with a nutrient solution at an EC of $1.2 \mathrm{dS} \cdot \mathrm{m}^{-1}(\mathrm{control})$ or a saline solution at an EC of $5.0 \mathrm{dS} \cdot \mathrm{m}^{-1}$ (EC 5) or $10.0 \mathrm{dS} \cdot \mathrm{m}^{-1}$ (EC 10) over the course of experiment. Treatment solutions were applied from 9 Aug. to 9 Nov. 2019 (24 irrigation events). Vertical bars represent SEs of 12 and 11 measurements, respectively, before and after Acorus gramineus was harvested on 10 Oct. 2019 (16 irrigation events).
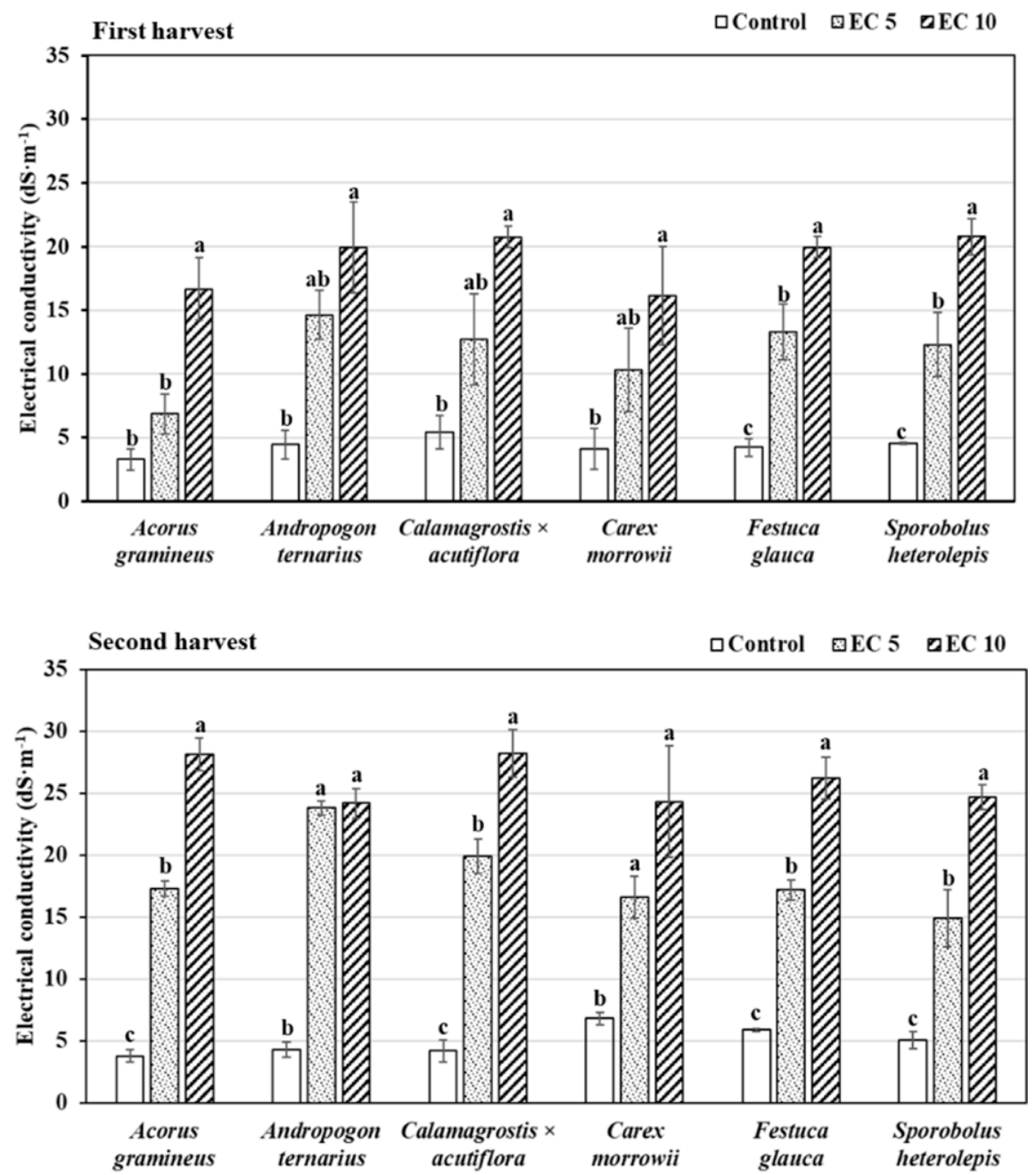

Fig. 2. Electrical conductivity (EC) of soil extraction for ornamental grasses irrigated with a nutrient solution at an EC of $1.2 \mathrm{dS} \cdot \mathrm{m}^{-1}$ (control) or a saline solution at an EC of 5.0 or $10.0 \mathrm{dS} \cdot \mathrm{m}^{-1}$. Treatment solutions were applied from 9 Aug. to 22 Sept. 2019 (12 irrigation events) before first harvest. Treatment solutions were applied to all grass species from 9 Aug. to 9 Nov. 2019 (24 irrigation events) before second harvest, with the exception of Acorus gramineus, which was irrigated from 9 Aug. to 8 Oct. 2019 (16 irrigation events). Vertical bars represent SES of three measurements. Same letters above columns within species represent no significance among treatments as determined by Tukey's method for multiplicity at $\alpha=0.05$. current study were relatively lower than those reported in our previous research on ornamental grasses (Wang et al., 2019). This discrepancy is caused by the high leaching fraction applied in this study. However, in nursery production, it is becoming increasingly difficult to reconcile the high leaching fraction practice in light of our concerns over diminishing water supplies and groundwater quality. Foliar salt damage is an important parameter to assess when measuring salt tolerance (Niu and Cabrera, 2010), and plant species showing severe salt injury early in the study are less tolerant to salinity stress. Therefore, A. gramineus was the most salt-sensitive species, while $C$. $\times$ acutiflora was the most tolerant species. Festuca glauca and S. heterolepis are more tolerant than $A$. ternarius or $C$. morrowii to salinity levels in this study. Sporobolus virginicus (seashore dropseed), a halophytic turfgrass, had no visible salt damage when treated with $1500 \mathrm{~mm} \mathrm{NaCl}\left(\approx 110 \mathrm{dS} \cdot \mathrm{m}^{-1}\right)$ for 6 weeks (Tada et al., 2014). Plant species in Andropogon are probably moderately salt-tolerant as Redmann (1972) reported that Andropogon scoparius (little bluestem) and Andropogon gerardii (big bluestem grass) are found naturally in wet locations with non-saline surface soil $\left(\approx 2.1 \mathrm{dS} \cdot \mathrm{m}^{-1}\right.$ for 0 to $10 \mathrm{~cm}$ soil) and moderately saline subsoil $\left(\approx 7.7 \mathrm{dS} \cdot \mathrm{m}^{-1}\right.$ for 40 to $50 \mathrm{~cm}$ soil $)$.

Plant growth. Irrigation with saline solution treatments significantly inhibited plant growth $(P<0.0001)$ for both harvest dates (Table 3 ). At the first harvest, all grass species irrigated with saline solution at an EC of 5.0 or $10.0 \mathrm{dS} \cdot \mathrm{m}^{-1}$ were $9 \%$ to $20 \%$ and $16 \%$ to $39 \%$ shorter than those in the control, respectively, with the exception of $F$. glauca plants that had similar height among three treatments. At the second harvest, A. gramineus, A. ternarius, C. $\times$ acutiflora, and $C$. morrowii irrigated with saline solution at an EC of 5.0 or $10.0 \mathrm{dS} \cdot \mathrm{m}^{-1}$ had $16 \%$ to $20 \%$ and $27 \%$ to $45 \%$ reductions in height, respectively, compared with the control. Festuca 
glauca plants were $14 \%$ shorter than the control when they were irrigated with saline solution at an EC of $10.0 \mathrm{dS} \cdot \mathrm{m}^{-1}$. Similarly, Sun and Palmer (2018) documented that ornamental grass and grass-like plants had a $10 \%$ to $38 \%$ reduction in height compared with the control when irrigated with saline solution at an EC of $10.0 \mathrm{dS} \cdot \mathrm{m}^{-1}$ for 9 weeks. Plant height of $S$. heterolepis was the same among three treatments (Table 3), which is similar to a previous report of a 20 -week greenhouse study by Hunter and Wu (2005) in which plant height of Sporobolus airoides (alkali sacaton) was not significantly impacted by increasing $\mathrm{NaCl}$ concentration in irrigation water applied via sprinkler system. Conversely, in a 12-week study, S. virginicus had significant reductions in plant height with increasing salinity levels (Naidoo and Naidoo, 1998). This contrast might suggest that salinity tolerance of Sporobolus is species-dependent.

Saline irrigation affected plant leaf area $(P<0.0001)$ for both harvest dates with different responses among grass species (Table 4). At the first harvest, compared with the control, $A$. gramineus and $C$. $\times$ acutiflora irrigated with saline solution at an EC of $5.0 \mathrm{dS} \cdot \mathrm{m}^{-1}$ had $43 \%$ and $39 \%$ reductions in leaf area, respectively. In the same treatment, no statistical difference was observed in the leaf area of $C$. morrowii, compared with the control, despite a decrease of $30 \%$. Compared with the control, leaf area was decreased by $48 \%$ to $60 \%$ for $A$. gramineus, $C$. $\times$ acutiflora, and $C$. morrowii irrigated with saline solution at an EC of $10.0 \mathrm{dS} \cdot \mathrm{m}^{-1}$. In the same treatment, no statistical difference was observed in leaf area of $A$. ternarius, despite a decrease of $35 \%$ compared with the control. Additionally, no differences were observed in the leaf area of F. glauca and S. heterolepis among treatments. At the second harvest, all grass species irrigated with saline solution at an EC of $5.0 \mathrm{dS} \cdot \mathrm{m}^{-1}$ had $35 \%$ to $53 \%$ smaller leaf area than those in the control, with the exception of $A$. ternarius and $F$. glauca. When irrigated with saline solution at an EC of $10.0 \mathrm{dS} \cdot \mathrm{m}^{-1}$, leaf area of all grass species decreased by $32 \%$ to $76 \%$ compared with the control. This is in line

Table 3. Plant height of six ornamental grasses irrigated with a nutrient solution [electrical conductivity $(\mathrm{EC})=1.2 \mathrm{dS} \cdot \mathrm{m}^{-1}$; control] or a saline solution $\left[\mathrm{EC}=5.0 \mathrm{dS} \cdot \mathrm{m}^{-1}\right.$ (EC 5) or $10.0 \mathrm{dS} \cdot \mathrm{m}^{-1}$ (EC 10)] in a greenhouse. ${ }^{\mathrm{z}}$

\begin{tabular}{|c|c|c|c|c|c|c|}
\hline \multirow[b]{3}{*}{ Taxa } & \multicolumn{6}{|c|}{ Plant ht $(\mathrm{cm})$} \\
\hline & \multicolumn{3}{|c|}{ First harvest $(\mathrm{n}=10)$} & \multicolumn{3}{|c|}{ Second harvest $(n=5)$} \\
\hline & Control & EC 5 & EC 10 & Control & EC 5 & EC 10 \\
\hline$\overline{\text { Acorus gramineus }}$ & $12.6 \mathrm{a}^{\mathrm{y}}$ & $10.7 \mathrm{~b}$ & $8.8 \mathrm{c}$ & $13.4 \mathrm{a}$ & $11.1 \mathrm{~b}$ & $-^{x}$ \\
\hline Andropogon ternarius & $65.8 \mathrm{a}$ & $52.5 \mathrm{~b}$ & $39.9 \mathrm{c}$ & $69.4 \mathrm{a}$ & $55.6 \mathrm{~b}$ & $40.9 \mathrm{c}$ \\
\hline Calamagrostis $\times$ acutiflora & $78.6 \mathrm{a}$ & $68.0 \mathrm{~b}$ & $55.8 \mathrm{c}$ & $89.2 \mathrm{a}$ & $74.9 \mathrm{~b}$ & $65.2 \mathrm{c}$ \\
\hline Carex morrowii & $36.2 \mathrm{a}$ & $28.8 \mathrm{~b}$ & $22.0 \mathrm{c}$ & $44.8 \mathrm{a}$ & $37.2 \mathrm{~b}$ & $24.5 \mathrm{c}$ \\
\hline Festuca glauca & $17.7 \mathrm{a}$ & $17.9 \mathrm{a}$ & $16.7 \mathrm{a}$ & $20.0 \mathrm{ab}$ & $22.8 \mathrm{a}$ & $17.3 \mathrm{~b}$ \\
\hline Sporobolus heterolepis & $75.0 \mathrm{a}$ & $68.4 \mathrm{ab}$ & $62.7 \mathrm{~b}$ & $83.9 \mathrm{a}$ & $79.5 \mathrm{a}$ & $75.8 \mathrm{a}$ \\
\hline
\end{tabular}

${ }^{\mathrm{z}}$ Grasses were harvested at $47 \mathrm{~d}$ (12 irrigation events, first harvest) and $95 \mathrm{~d}$ (24 irrigation events, second harvest) after the initiation of treatments except $A$. gramineus, which was harvested at $62 \mathrm{~d}$ (16 irrigation events, second harvest) after the initiation of treatments because A. gramineus was dead when irrigated with saline solution at an EC of $10.0 \mathrm{dS} \cdot \mathrm{m}^{-1}$.

${ }^{y}$ Means with same lowercase letters within a row and harvest date are not significantly different among treatments by Tukey's method for multiplicity at $\alpha=0.05$.

${ }^{\mathrm{x}}$ A. gramineus was dead.

Table 4. Leaf area of six ornamental grasses irrigated with a nutrient solution [electrical conductivity $(\mathrm{EC})=1.2 \mathrm{dS} \cdot \mathrm{m}^{-1}$; control] or a saline solution $\left[\mathrm{EC}=5.0 \mathrm{dS} \cdot \mathrm{m}^{-1}\right.$ (EC 5) or $\left.10.0 \mathrm{dS} \cdot \mathrm{m}^{-1}(\mathrm{EC} 10)\right]$ in a greenhouse. ${ }^{\mathrm{Z}}$

\begin{tabular}{|c|c|c|c|c|c|c|}
\hline \multirow[b]{3}{*}{ Taxa } & \multicolumn{6}{|c|}{ Leaf area $\left(\mathrm{cm}^{2}\right)$} \\
\hline & \multicolumn{3}{|c|}{ First harvest $(\mathrm{n}=5)$} & \multicolumn{3}{|c|}{ Second harvest $(n=5)$} \\
\hline & Control & EC 5 & EC 10 & Control & EC 5 & EC 10 \\
\hline Acorus gramineus & $654 \mathrm{a}^{\mathrm{y}}$ & $372 \mathrm{~b}$ & $259 \mathrm{~b}$ & $899 a$ & $423 \mathrm{~b}$ & $-\mathrm{x}$ \\
\hline Andropogon ternarius & $1530 \mathrm{a}$ & $1328 \mathrm{a}$ & $990 \mathrm{a}$ & $1870 \mathrm{a}$ & $1626 \mathrm{ab}$ & $1270 \mathrm{~b}$ \\
\hline Calamagrostis $\times$ acutiflora & $1391 \mathrm{a}$ & 844 b & $573 \mathrm{~b}$ & $3074 \mathrm{a}$ & $1722 \mathrm{~b}$ & $1136 \mathrm{c}$ \\
\hline Carex morrowii & $640 \mathrm{a}$ & $450 \mathrm{ab}$ & $334 \mathrm{~b}$ & $1372 \mathrm{a}$ & 892 b & $325 \mathrm{c}$ \\
\hline Festuca glauca & $193 \mathrm{a}$ & $249 \mathrm{a}$ & $171 \mathrm{a}$ & $633 \mathrm{a}$ & $476 \mathrm{a}$ & $283 \mathrm{~b}$ \\
\hline Sporobolus heterolepis & $253 \mathrm{a}$ & $271 \mathrm{a}$ & $262 \mathrm{a}$ & $1837 \mathrm{a}$ & $1175 \mathrm{~b}$ & $660 \mathrm{c}$ \\
\hline
\end{tabular}

${ }^{\mathrm{z}}$ Grasses were harvested at $47 \mathrm{~d}$ (12 irrigation events, first harvest) and $95 \mathrm{~d}$ (24 irrigation events, second harvest) after the initiation of treatments except $A$. gramineus, which was harvested at $62 \mathrm{~d}$ (16 irrigation events, second harvest) after the initiation of treatments because A. gramineus was dead when irrigated with saline solution at an EC of $10.0 \mathrm{dS} \cdot \mathrm{m}^{-1}$.

${ }^{y}$ Means with same lowercase letters within a row and harvest date are not significantly different among treatments by Tukey's method for multiplicity at $\alpha=0.05$.

${ }^{\mathrm{x}}$ A. gramineus was dead. with previous reports that decreased leaf area of ornamental grasses was observed in response to salinity stress (Sun and Palmer, 2018; Wang et al., 2019).

Saline irrigation also influenced the number of tillers of ornamental grasses $(P<$ $0.0001)$ measured at both harvest dates (Table 5). At the first harvest, the number of tillers decreased by $26 \%$ to $33 \%$ when $A$. gramineus, $C$. ×acutiflora, C. morrowii, and $S$. heterolepis were irrigated with saline solution at an EC of $5.0 \mathrm{dS} \cdot \mathrm{m}^{-1}$, but these values were not significantly different from the control. Acorus gramineus developed 51\% fewer tillers than the control when irrigated with saline solution at an EC of $10.0 \mathrm{dS} \cdot \mathrm{m}^{-1}$. In the same treatment, there was a $25 \%$ to $42 \%$ reduction in the number of tillers for A. ternarius, C. ×acutiflora, C. morrowii, F. glauca, and $S$. heterolepis, but these values did not statistically differ from the control. At the second harvest, $A$. gramineus, $C$. $\times$ acutiflora, and $S$. heterolepis plants irrigated with saline solution at an EC of $5.0 \mathrm{dS} \cdot \mathrm{m}^{-1}$ had $39 \%$, $20 \%$, and $26 \%$ fewer tillers than the control, respectively. There were $24 \%$ to $70 \%$ reductions in the number of tillers when grass species were irrigated with saline solution at an EC of $10.0 \mathrm{dS} \cdot \mathrm{m}^{-1}$. Elevated salinity levels in irrigation water have been observed to negatively affect tiller formation of E. spectabilis and $S$. scoparium (Wang et al., 2019). There was a slight reduction in the number of tillers of Bouteloua gracilis (blue grama), Chasmanthium latifolium (Indian seaoats), Leymus arenarius (sand ryegrass), Juncus effusus (common rush), and M. capillaris with increasing salinity levels. Carex vulpinoidea (fox edge) and Pennisetum alopecuroides (fountain grass) irrigated with saline solution at an EC of $10.0 \mathrm{dS} \cdot \mathrm{m}^{-1}$ for 18 weeks had $26 \%$ and $23 \%$ fewer tillers compared with the control, respectively (Sun and Palmer, 2018). Ruess et al. (1997) also reported that the number of tillers significantly reduced in Carex ramenskii (Ramensk's sedge) treated for 12 weeks with $19,500 \mathrm{mg} \cdot \mathrm{L}^{-1}(\approx 24.4$ $\left.\mathrm{dS} \cdot \mathrm{m}^{-1}\right) \mathrm{NaCl}$ compared with the control.

Irrigation with saline solution affected shoot dry weight $(P<0.0001)$ for both harvest dates, with varying responses among grass species (Table 6). At the first harvest, $C$. $\times$ acutiflora and C. morrowii produced $37 \%$ and $34 \%$ less shoot dry weight, respectively, than the control when they were irrigated with saline solution at an EC of $5.0 \mathrm{dS} \cdot \mathrm{m}^{-1}$. In the same treatment, no statistical difference was observed in shoot dry weight of $A$. gramineus, despite a decrease of $23 \%$. Compared with the control, shoot dry weight of A. gramineus, C. ×acutiflora, and C. morrowii irrigated with saline solution at an EC of $10.0 \mathrm{dS} \cdot \mathrm{m}^{-1}$ was reduced by $37 \%, 52 \%$, and $47 \%$, respectively. In the same treatment, no statistical difference was observed in shoot dry weight of A. ternarius, despite a decrease of $27 \%$. No significant changes, in comparison with the control, were observed in shoot dry weight of $F$. glauca and S. heterolepis when they were irrigated with saline solution at an EC of 5.0 or $10.0 \mathrm{dS} \cdot \mathrm{m}^{-1}$. At the second harvest, shoot 
Table 5. Number of tillers of six ornamental grasses irrigated with a nutrient solution [electrical conductivity $(\mathrm{EC})=1.2 \mathrm{dS} \cdot \mathrm{m}^{-1}$; control] or a saline solution $\left[\mathrm{EC}=5.0 \mathrm{dS} \cdot \mathrm{m}^{-1}\right.$ (EC 5) or 10.0 $\left.\mathrm{dS} \cdot \mathrm{m}^{-1}(\mathrm{EC} 10)\right]$ in a greenhouse. ${ }^{\mathrm{z}}$

\begin{tabular}{|c|c|c|c|c|c|c|}
\hline \multirow[b]{3}{*}{ Taxa } & \multicolumn{6}{|c|}{ Tiller (no.) } \\
\hline & \multicolumn{3}{|c|}{ First harvest $(\mathrm{n}=5)$} & \multicolumn{3}{|c|}{ Second harvest $(n=5)$} \\
\hline & Control & EC 5 & EC 10 & Control & EC 5 & EC 10 \\
\hline Acorus gramineus & $182 \mathrm{a}^{\mathrm{y}}$ & $134 \mathrm{ab}$ & $90 \mathrm{~b}$ & $222 \mathrm{a}$ & $135 \mathrm{~b}$ & $-{ }^{x}$ \\
\hline Andropogon ternarius & $177 \mathrm{a}$ & $155 \mathrm{a}$ & $133 \mathrm{a}$ & $121 \mathrm{a}$ & $104 \mathrm{ab}$ & $89 \mathrm{~b}$ \\
\hline Calamagrostis $\times$ acutiflora & $127 \mathrm{a}$ & $85 \mathrm{a}$ & $77 \mathrm{a}$ & $133 \mathrm{a}$ & $107 \mathrm{~b}$ & $101 \mathrm{~b}$ \\
\hline Carex morrowii & $12 \mathrm{a}$ & $8 \mathrm{a}$ & $7 \mathrm{a}$ & $30 \mathrm{a}$ & $25 \mathrm{a}$ & $9 \mathrm{~b}$ \\
\hline Festuca glauca & $138 \mathrm{a}$ & $149 \mathrm{a}$ & 88 a & $95 \mathrm{a}$ & $78 \mathrm{a}$ & $61 \mathrm{~b}$ \\
\hline Sporobolus heterolepis & $65 \mathrm{a}$ & $44 \mathrm{a}$ & $41 \mathrm{a}$ & $69 \mathrm{a}$ & $51 \mathrm{~b}$ & $37 \mathrm{c}$ \\
\hline
\end{tabular}

${ }^{\bar{z}}$ Grasses were harvested at $47 \mathrm{~d}$ (12 irrigation events, first harvest) and $95 \mathrm{~d}$ (24 irrigation events, second harvest) after the initiation of treatments except A. gramineus, which was harvested at $62 \mathrm{~d}$ (16 irrigation events, second harvest) after the initiation of treatments because A. gramineus was dead when irrigated with saline solution at an EC of $10.0 \mathrm{dS} \cdot \mathrm{m}^{-1}$.

${ }^{\mathrm{y}}$ Means with same lowercase letters within a row and harvest date are not significantly different among treatments by Tukey's method for multiplicity at $\alpha=0.05$.

${ }^{\mathrm{x}}$ A. gramineus was dead.

Table 6. Shoot dry weight of six ornamental grasses irrigated with a nutrient solution [electrical conductivity $(\mathrm{EC})=1.2 \mathrm{dS} \cdot \mathrm{m}^{-1}$; control] or a saline solution $\left[\mathrm{EC}=5.0 \mathrm{dS} \cdot \mathrm{m}^{-1}(\mathrm{EC} 5)\right.$ or 10.0 $\left.\mathrm{dS} \cdot \mathrm{m}^{-1}(\mathrm{EC} 10)\right]$ in a greenhouse. ${ }^{\mathrm{z}}$

\begin{tabular}{|c|c|c|c|c|c|c|}
\hline \multirow[b]{3}{*}{ Taxa } & \multicolumn{6}{|c|}{ Shoot dry wt (g) } \\
\hline & \multicolumn{3}{|c|}{ First harvest $(n=5)$} & \multicolumn{3}{|c|}{ Second harvest $(n=5)$} \\
\hline & Control & EC 5 & EC 10 & Control & EC 5 & EC 10 \\
\hline$\overline{\text { Acorus gramineus }}$ & $7.3 \mathrm{a}^{\mathrm{y}}$ & $5.6 \mathrm{ab}$ & $4.6 \mathrm{~b}$ & $13.3 \mathrm{a}$ & $11.4 \mathrm{a}$ & $-{ }^{x}$ \\
\hline Andropogon ternarius & $31.5 \mathrm{a}$ & $29.3 \mathrm{a}$ & $22.9 \mathrm{a}$ & $64.6 \mathrm{a}$ & $54.9 \mathrm{ab}$ & $40.9 \mathrm{~b}$ \\
\hline Calamagrostis $\times$ acutiflora & 30.9 a & $19.4 \mathrm{~b}$ & $15.0 \mathrm{~b}$ & $110.7 \mathrm{a}$ & $58.1 \mathrm{~b}$ & $38.6 \mathrm{c}$ \\
\hline Carex morrowii & $9.2 \mathrm{a}$ & $6.1 \mathrm{~b}$ & $4.9 \mathrm{~b}$ & $33.4 \mathrm{a}$ & $21.4 \mathrm{~b}$ & $6.9 \mathrm{c}$ \\
\hline Festuca glauca & $6.6 \mathrm{a}$ & $8.5 \mathrm{a}$ & $6.9 \mathrm{a}$ & $18.2 \mathrm{a}$ & $16.8 \mathrm{a}$ & $10.6 \mathrm{~b}$ \\
\hline Sporobolus heterolepis & $9.3 \mathrm{a}$ & $8.5 \mathrm{a}$ & $9.6 \mathrm{a}$ & $75.7 \mathrm{a}$ & $47.8 \mathrm{~b}$ & $30.2 \mathrm{c}$ \\
\hline
\end{tabular}

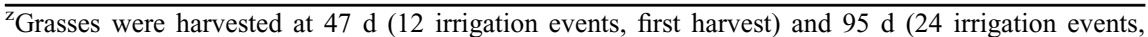
second harvest) after the initiation of treatments except $A$. gramineus, which was harvested at $62 \mathrm{~d}$ (16 irrigation events, second harvest) after the initiation of treatments because A. gramineus was dead when irrigated with saline solution at an EC of $10.0 \mathrm{dS} \cdot \mathrm{m}^{-1}$

${ }^{\mathrm{y}}$ Means with same lowercase letters within a row and harvest date are not significantly different among treatments by Tukey's method for multiplicity at $\alpha=0.05$.

${ }^{\mathrm{x}}$ A. gramineus was dead.

dry weight of $C$. ×acutiflora, C. morrowii, and $S$. heterolepis decreased by $48 \%, 36 \%$, and $37 \%$, respectively, when irrigated with saline solution at an EC of $5.0 \mathrm{dS} \cdot \mathrm{m}^{-1}$. All grass species except $A$. gramineus had $37 \%$ to $79 \%$ reductions in shoot dry weight when irrigated with saline solution at an EC of $10.0 \mathrm{dS} \cdot \mathrm{m}^{-1}$, compared with the control. Similarly, with increasing salinity levels, there was a decrease in biomass production of Andropogon glomeratus (bushy bluestem) (Bowman and Strain, 1988). This also aligns with previous work documenting that Carex rigescens (rigescent sedge), Carex rostrata (beaked sedge), and Carex pilosa (hairy sedge) had reduced growth under salinity stress (Choo et al., 2001; Li et al., 2018). Likewise, there was a $40 \%$ reduction in total plant mass of $\mathrm{C}$. $\mathrm{ra}$ menskii when treated with $19,500 \mathrm{mg} \cdot \mathrm{L}^{-1}$ $\mathrm{NaCl}\left(\approx 24.4 \mathrm{dS} \cdot \mathrm{m}^{-1}\right)$ compared with the control (Ruess et al., 1997). LeCompte et al. (2016) also reported that shoot dry weight of $M$. capillaris decreased with increasing concentrations of $\mathrm{NaCl}$ from 2000 to 10,000 $\mathrm{mg} \cdot \mathrm{L}^{-1}\left(\approx 3.1\right.$ to $\left.12.5 \mathrm{dS} \cdot \mathrm{m}^{-1}\right)$. On the other gramineus as a moderately salt-tolerant plant and describe it as a species that "can tolerate some salt spray, but grow best when protected by other plants, structures or dunes" (Rockaway, Inc., 2020). Calamagrostis $\times$ acutiflora did not show any foliar salt damage during this 95-d experiment, although saline solution irrigation inhibited plant growth and development (Tables 3-6). This research-based information supports the anecdotal observation made by Jull (2009) that $C$. $\times$ acutiflora 'Karl Foerster' is considered tolerant of high soil-salinity. Saline irrigation had little effect on plant growth and visual quality of $F$. glauca and $S$. heterolepis at the first harvest, but at the second harvest, slight foliar salt damage occurred and plant growth and development were significantly affected, especially with saline solution at an EC of $10.0 \mathrm{dS} \cdot \mathrm{m}^{-1}$ (Tables 3-6). Massahi et al. (2018) reported that lawn quality of Festuca arundinacea (tall fescue) was unaffected by saline irrigation at an EC of $12.0 \mathrm{dS} \cdot \mathrm{m}^{-1}$ for 7 months. Andropogon ternarius and $C$. morrowii exhibited slight foliar salt damage and reduced plant growth at the first harvest and moderate foliar salt damage and further reduced plant growth at the second harvest (Tables 3-6). Carex rigescens, a turfgrass species, had decreased turf quality rating when irrigated for $7 \mathrm{~d}$ with $\mathrm{NaCl}$ concentration greater than $300 \mathrm{~mm}\left(\approx 21.9 \mathrm{dS} \cdot \mathrm{m}^{-1}\right)$ (Li et al., 2018). Carex vulpinoidea showed slight to moderate foliar salt damage when irrigated with saline solution at an EC of 5.0 or $10.0 \mathrm{dS} \cdot \mathrm{m}^{-1}$ for 18 weeks (Sun and Palmer, 2018).

Leaf greenness ( $S P A D$ reading) and gas exchange. Saline irrigation had significant effects on the leaf greenness of ornamental grasses as inferred by SPAD readings $(P<$ 0.0001 ) at both harvest dates (Fig. 3). There was no difference among the three treatments in SPAD readings of $C$. $\times$ acutiflora at both harvest dates, $S$. heterolepis at the first harvest, and A. ternarius at the second harvest (Fig. 3). Compared with the control, SPAD readings of $C$. morrowii irrigated with saline solution at an EC of $5.0 \mathrm{dS} \cdot \mathrm{m}^{-1}$ were reduced by $12 \%$ for both harvest dates. At the first harvest, compared with the control, SPAD readings of $A$. ternarius and $C$. morrowii irrigated with saline solution at an EC of 10.0 $\mathrm{dS} \cdot \mathrm{m}^{-1}$ decreased by $29 \%$ and $31 \%$, respectively. At the second harvest, SPAD readings of $C$. morrowii and $S$. heterolepis were reduced by $36 \%$ and $20 \%$, respectively, compared with the control, when they were irrigated with saline solution at an EC of 10.0 $\mathrm{dS} \cdot \mathrm{m}^{-1}$. These results are in line with previous research by Li et al. (2018) that reported $C$. rigescens experienced chlorophyll degradation with increasing salinity levels in irrigation water. In addition, SPAD readings of $A$. ternarius were significantly higher at the first harvest than the second harvest $(P<0.0001)$, regardless of treatments. This might be associated with plant growth stage because $A$. ternarius blooms in the fall (Hoffman Nursery, 

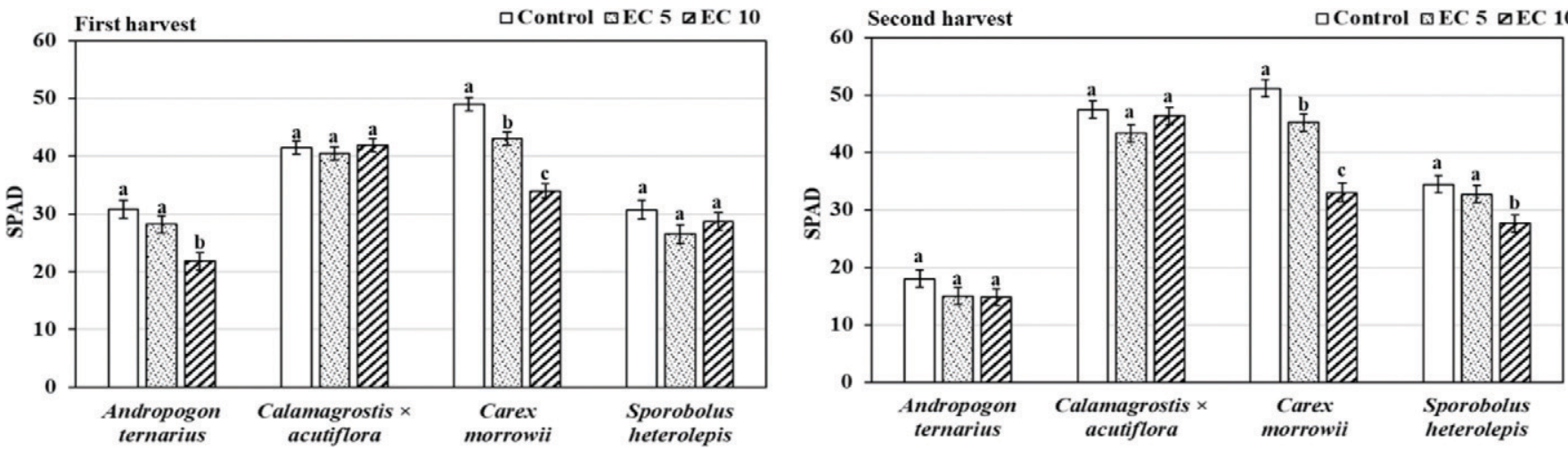

Fig. 3. Relative chlorophyll content [soil plant analysis development (SPAD) reading] of ornamental grasses irrigated with a nutrient solution [electrical conductivity $(\mathrm{EC})=1.2 \mathrm{dS} \cdot \mathrm{m}^{-1}$; control] or a saline solution $\left[\mathrm{EC}=5.0 \mathrm{dS} \cdot \mathrm{m}^{-1}(\mathrm{EC} 5)\right.$ or $10.0 \mathrm{dS} \cdot \mathrm{m}^{-1}$ (EC 10)] in a greenhouse. Treatment solutions were applied from 9 Aug. to 9 Nov. 2019 (24 irrigation events). All grasses were harvested at $47 \mathrm{~d}$ (12 irrigation events, first harvest) and $95 \mathrm{~d}$ ( 24 irrigation events, second harvest) after the initiation of treatments. SPAD was not taken for Acorus gramineus and Festuca glauca because of narrow leaves. Vertical bars represent SES of 10 and 5 measurements for the first and second harvest, respectively. Same letters above columns within species represent no significance among treatments as determined by Tukey's method for multiplicity at $\alpha=0.05$.

2020), which can draw resources from the foliage and hence reduce foliar quality.

Saline irrigation had significant effects on $\mathrm{P}_{\mathrm{n}}(P<0.0001)$ and $g_{\mathrm{S}}(P<0.001)$ for both harvest dates (Fig. 4). At the first harvest, compared with the control, saline solution at an EC of $5.0 \mathrm{dS} \cdot \mathrm{m}^{-1}$ reduced $\mathrm{P}_{\mathrm{n}}$ of C. $\times$ acutiflora by $36 \%$. The $\mathrm{P}_{\mathrm{n}}$ of $A$. ternarius, $C$. $\times$ acutiflora, $C$. morrowii, and $S$. heterolepis decreased by $75 \%, 60 \%, 60 \%$, and $37 \%$, respectively, when irrigated with saline solution at an EC of $10.0 \mathrm{dS} \cdot \mathrm{m}^{-1}$. At the second harvest, compared with the control, A. ternarius, $C$. morrowii, and $S$. heterolepis had $56 \%, 69 \%$, and $83 \%$ reductions in $\mathrm{P}_{\mathrm{n}}$, respectively, when irrigated with saline solution at an EC of 10.0 $\mathrm{dS} \cdot \mathrm{m}^{-1}$. Yet no difference was observed for $C$. $\times$ acutiflora under these same conditions. Similarly, Vitt et al. (2020) observed a $41 \%$ decline in $\mathrm{P}_{\mathrm{n}}$ in $C$. aquatilis (water sedge) at the $2354 \mathrm{mg} \cdot \mathrm{L}^{-1}$ sodium treatment compared with $14 \mathrm{mg} \cdot \mathrm{L}^{-1}$ sodium treatment after 15 weeks. At the first harvest, compared with the control, the $g_{\mathrm{S}}$ of $A$. ternarius and $C$. ×acutiflora was reduced by $40 \%$ and $55 \%$, respectively,
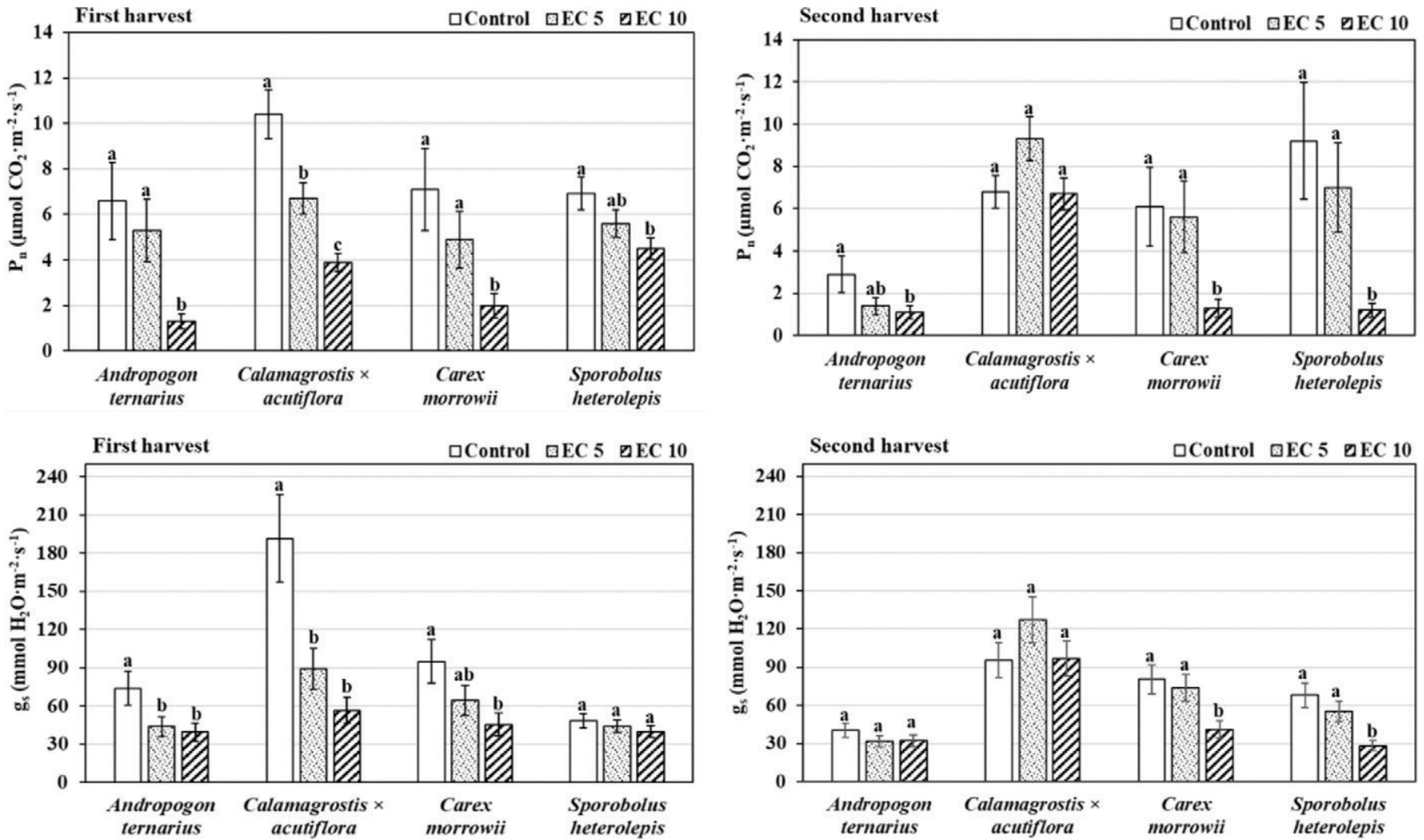

Fig. 4. Net photosynthetic rate $\left(\mathrm{P}_{\mathrm{n}}\right)$ and stomatal conductance $\left(g_{\mathrm{S}}\right)$ of ornamental grasses irrigated with a nutrient solution [electrical conductivity $(\mathrm{EC})=1.2$ $\mathrm{dS} \cdot \mathrm{m}^{-1}$; control] or a saline solution $\left[\mathrm{EC}=5.0 \mathrm{dS} \cdot \mathrm{m}^{-1}(\mathrm{EC} 5)\right.$ or $10.0 \mathrm{dS} \cdot \mathrm{m}^{-1}$ (EC 10)] in a greenhouse. Treatment solutions were applied from 9 Aug. to 9 Nov. 2019 (24 irrigation events). All grasses were harvested at $47 \mathrm{~d}$ (12 irrigation events, first harvest) and $95 \mathrm{~d}$ (24 irrigation events, second harvest) after the initiation of treatments. Gas exchange was not taken for Acorus gramineus and Festuca glauca because of narrow leaves. Vertical bars represent SES of five measurements. Same letters above columns within species represent no significance among treatments as determined by Tukey's method for multiplicity at $\alpha=0.05$. 
when irrigated with saline solution at an EC of $5.0 \mathrm{dS} \cdot \mathrm{m}^{-1}$ (Fig. 4). When irrigated with saline solution at an EC of $10.0 \mathrm{dS} \cdot \mathrm{m}^{-1}$, the $g_{\mathrm{S}}$ of $A$. ternarius, $C$. $\times$ acutiflora, and $C$. morrowii was reduced by $34 \%, 65 \%$, and $45 \%$, respectively, compared with the control. Although the $g_{\mathrm{S}}$ of $S$. heterolepis decreased, there was no statistical difference. At the second harvest, when irrigated with saline solution at an EC of $10.0 \mathrm{dS} \cdot \mathrm{m}^{-1}$, the $g_{\mathrm{S}}$ of $C$. morrowii and $S$. heterolepis was reduced by $50 \%$ and $57 \%$, respectively. There was no difference in the $g_{\mathrm{S}}$ of $A$. ternarius and C. $\times$ acutiflora among the three treatments. Corroborating these results, Bowman (1987) reported that net $\mathrm{CO}_{2}$ uptake and $g_{\mathrm{S}}$ of $A$. glomeratus decreased with increasing salinity levels in irrigation water. Similarly, Vitt et al. (2020) observed a $55 \%$ decrease in $g_{\mathrm{S}}$ in $C$. aquatilis at a $2354 \mathrm{mg} \cdot \mathrm{L}^{-1}$ sodium treatment compared with $14 \mathrm{mg} \cdot \mathrm{L}^{-1}$ sodium treatment after 15 weeks. Finally, $\mathrm{NaCl}$ application at $250 \mathrm{~mm}\left(\approx 18.3 \mathrm{dS} \cdot \mathrm{m}^{-1}\right)$ over $24 \mathrm{~d}$ reduced the net $\mathrm{CO}_{2}$ assimilation and $g_{\mathrm{S}}$ of $F$. arundinacea (Pawlowicz et al., 2018).

Saline irrigation influenced $E(P<0.001)$ and WUE $(P<0.01)$ at both harvest dates
(Fig. 5). At the first harvest, $C$. $\times$ acutiflora irrigated with saline solution at an EC of 5.0 $\mathrm{dS} \cdot \mathrm{m}^{-1}$ had a $40 \%$ reduction in $E$ compared with the control. Andropogon ternarius, $C . \times$ acutiflora, and $C$. morrowii exhibited $25 \%$, $53 \%$, and $41 \%$ reductions in $E$ when they were irrigated with saline solution at an EC of $10.0 \mathrm{dS} \cdot \mathrm{m}^{-1}$. There was no difference in $E$ of $S$. heterolepis. At the second harvest, when they were irrigated with saline solution at an EC of $10.0 \mathrm{dS} \cdot \mathrm{m}^{-1}, C$. morrowii and S. heterolepis had $43 \%$ and $53 \%$ reductions in $E$, respectively. No difference in $E$ was recorded for $A$. ternarius and $C$. ×acutiflora. In line with these results, $C$. aquatilis subjected to a 15 -week $2354 \mathrm{mg} \cdot \mathrm{L}^{-1}$ sodium irrigation treatment had a $47 \%$ reduction in $E$ when compared with $14 \mathrm{mg} \cdot \mathrm{L}^{-1}$ sodium treatment (Vitt et al., 2020). At the first harvest, there were no differences in the WUE of $C$. $\times$ acutiflora and C. morrowii (Fig. 5). However, A. ternarius and $S$. heterolepis had $44 \%$ and $23 \%$ reductions in the WUE when they were irrigated with saline solution at an EC of $10.0 \mathrm{dS} \cdot \mathrm{m}^{-1}$. At the second harvest, $A$. ternarius, $C$. morrowii, and $S$. heterolepis irrigated with saline solution at an EC of $10.0 \mathrm{dS} \cdot \mathrm{m}^{-1}$ had $44 \%, 50 \%$, and $69 \%$ reductions in WUE, compared with the control. There was no difference in the WUE of $C$. ×acutiflora.

In conclusion, ornamental grasses in this study exhibited varying responses to saline irrigation over a 95-d study. Among the six grass species, A. gramineus was the most sensitive species with high mortality and poor visual quality. Andropogon ternarius and $C$. morrowii were less tolerant to salinity levels in the irrigation water than $F$. glauca and $S$. heterolepis. Andropogon ternarius and $C$. morrowii showed moderate foliar salt damage, whereas $F$. glauca and $S$. heterolepis had slight foliar salt damage at the end of the experiment. Plant growth and development of these four grass species were inhibited, to some extent, because of saline solution irrigation. Calamagrostis $\times$ acutiflora was the most tolerant species, not exhibiting any foliar salt damage, although plant growth and development were impaired. Overall, C. ×acutiflora, F. glauca, and $S$. heterolepis are more suitable for landscapes in which reclaimed water is used for irrigation as well as landscapes in salt-prone areas and coastal regions.
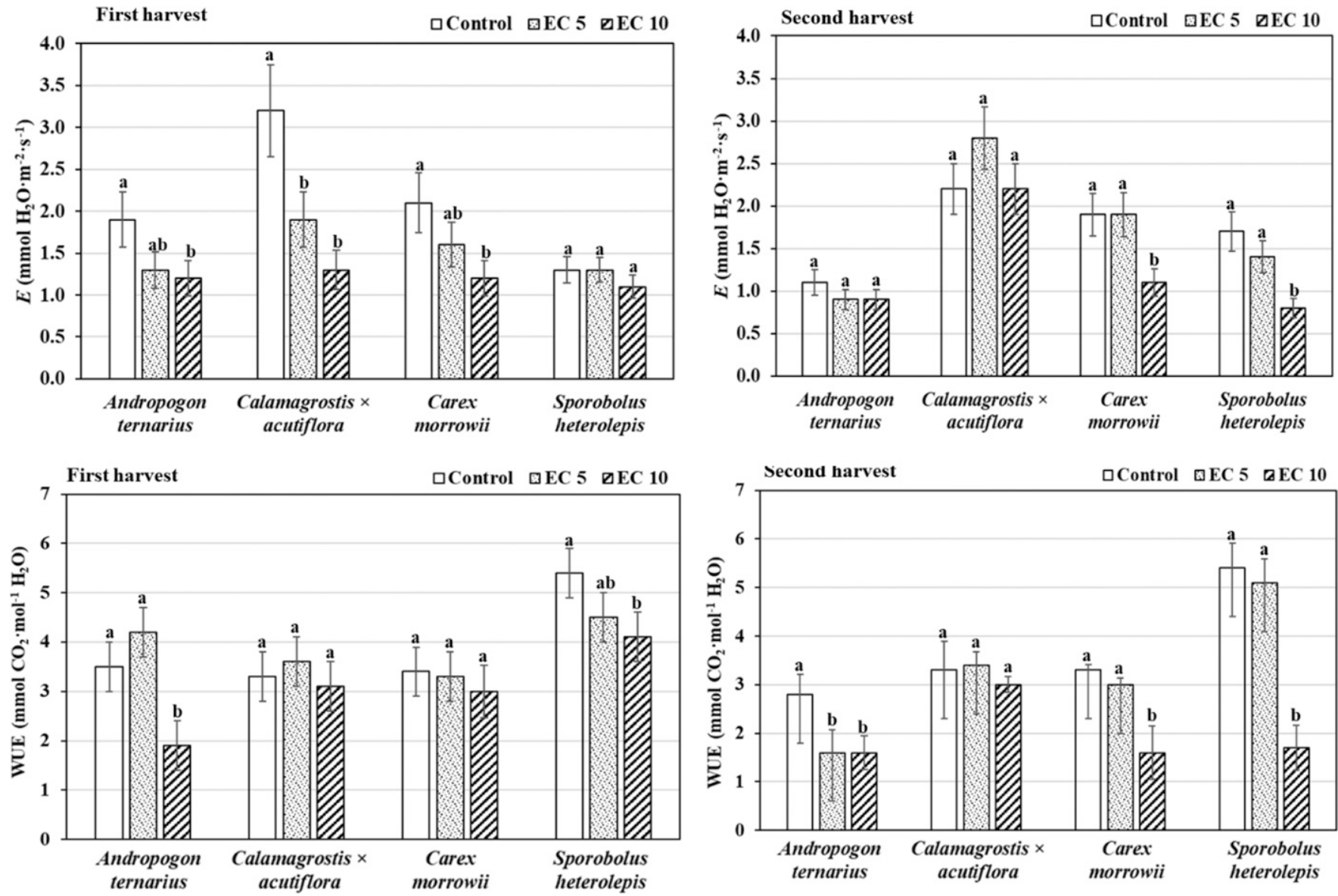

Fig. 5. Transpiration rate $(E)$ and water use efficiency (WUE) of ornamental grasses irrigated with a nutrient solution [electrical conductivity $($ EC) $=1.2$ $\mathrm{dS} \cdot \mathrm{m}^{-1}$; control] or a saline solution $\left[\mathrm{EC}=5.0 \mathrm{dS} \cdot \mathrm{m}^{-1}(\mathrm{EC} 5)\right.$ or $10.0 \mathrm{dS} \cdot \mathrm{m}^{-1}$ (EC 10)] in a greenhouse. Treatment solutions were applied from 9 Aug. to 9 Nov. 2019 (24 irrigation events). All grasses were harvested at $47 \mathrm{~d}$ (12 irrigation events, first harvest) and $95 \mathrm{~d}$ ( 24 irrigation events, second harvest) after the initiation of treatments. Gas exchange was not taken for Acorus gramineus and Festuca glauca because of narrow leaves. Vertical bars represent SES of five measurements. Same letters above columns within species represent no significance among treatments as determined by Tukey's method for multiplicity at $\alpha=0.05$. 


\section{Literature Cited}

Amacher, J.K., R. Koenig, and B. Kitchen. 2000. Salinity and plant tolerance. AG-SO03. Utah State Univ. Ext., Logan, UT. 12 Dec. 2020. $<$ https://digitalcommons.usu.edu/ extension_histall/43>

Bowman, W.D. and B.R. Strain. 1988. Response to long- and short-term salinity in populations of the $\mathrm{C}_{4}$ nonhalophyte Andropogon glomeratus Walter B.S.P. Oecologia 75:73-77.

Bowman, W.D. 1987. Effect of salinity on leaf gas exchange in two populations of a $\mathrm{C}_{4}$ nonhalophyte. Plant Physiol. 85:1055-1058, doi: 10.1007/BF00378816.

Choo, Y.S., S.D. Song, and R. Albert. 2001. Effects of salinity on growth and patterns of ions and organic solutes in five sedges (Carex spp.) with different ecological demands. Flora 196: 71-80, doi: 10.1016/S0367-2530(17)30014-2.

Gavlak, R.G., D.A. Horneck, and R.O. Miller. 1994. Plant, soil, and water reference methods for the western region. Western Regional Extension Publication (WREP) 125.

Ghassemi, F., A. Jakeman, and H. Nix. 1995. Salinization of land and water resources: Human causes, extent, management and case studies. UNSW Press, Sydney, Australia, and CAB International, Wallingforg, UK.

Gibson, J.L., D.S. Pitchay, A.L. Williams-Rhodes, B.E. Whipker, P.V. Nelson, and J.M. Dole. 2007. Nutrient deficiencies in bedding plants, a pictorial guide for identification and correction. Ball Publishing, Batavia, IL.

Gunnell, J., J. Goodspeed, and R.M. Anderson. 2015. Ornamental grasses in the landscape: A guide for the Intermountain West. Utah State Univ. Ext., Logan, UT. 12 Dec. 2020. <https:// digitalcommons.usu.edu/extension_curall/733/>.

Gulzar, S., M.A. Khan, and I.A. Ungar. 2003. Salt tolerance of a coastal salt marsh grass. Commun. Soil Sci. Plant Anal. 34:2595-2605, doi: 10.1081/CSS-120024787.

Hasegewa, P.M., R.A. Bressan, J.K. Zhu, and H.J. Bohnert. 2000. Plant cellular and molecular responses to high salinity. Annu. Rev. Plant Physiol. Mol. Biol. 51:463-499, doi: 10.1146/ annurev.arplant.51.1.463.

Hoffman Nursery. 2020. Andropogon ternarius 'Black Mountain' (black mountain bluestem). Hoffman Nursery, Rougemont, NC. 12 Dec. 2020. <http://www.hoffmannursery. com/plants $>$.

Hunter, K.A.M. and L. Wu. 2005. Morphological and physiological response of five California native grass species to moderate salt spray: Implications for landscape irrigation with reclaimed water. J. Plant Nutr. 28:247-270, doi: 10.1081/PLN-200047609.

Jull, L.G. 2009. Winter salt injury and salt-tolerant landscape plants. A3877. Univ. Wisconsin Coop. Ext. Madison, WI. 12 Dec. 2020. $<$ https://hort.extension.wisc.edu/articles/winter -salt-injury-and-salt-tolerant-landscape-plants/ $>$.

Khurram, S. and S. Miyamoto. 2005. Seedling growth, leaf injury and ion uptake response of cold-resistant palm species to salinity. J. Environ. Hort. 23:193-198, doi: 10.24266/07382898-23.4.193.
LeCompte, J.S., A.N. Wright, C.M. LeBleu, and J.R. Kessler. 2016. Saline irrigation affects growth and leaf tissue nutrient concentration of three native landscape plant species. HortTechnology 26:309-313, doi: 10.21273/HORTTECH.26.3.309.

Li, M., K. Zhang, Y. Sun, H. Cui, S. Cao, L. Yan, and M. Xu. 2018. Growth, physiology, and transcriptional analysis of two contrasting Carex rigescens genotypes under salt stress reveals salt-tolerance mechanisms. J. Plant Physiol. 229:77-88, doi: 10.1016/j.jplph.2018.07.005.

Mane, A.V., B.A. Karadge, and J.S. Samant. 2011 Salt stress induced alteration in growth characteristics of a grass Pennisetum alopecuroides. J. Environ. Biol. 32:753-758.

Massahi, S., D. Naderi, and M. Pessarakli. 2018. Studying the effect of two biological fertilizers on salt tolerance of tall fescue (Festuca arundinacea schreb.). J. Plant Nutr. 41:2210-2221, doi: 10.1080/01904167.2018.1500587.

McKenney, C.B., T.R. Mahato, and U.K. Schuch. 2016. Salinity tolerance of ornamental grasses adapted to semi-arid environments. International Horticultural Congress on Horticulture: Sustaining Lives, Livelihoods and Landscapes (IHC2014):95-99, doi: 10.17660/ActaHortic.2016.1112.13.

Missouri Botanical Garden. 2020. Carex morrowii. Missouri Botanical Garden, St. Louis, MO. 12 Dec. 2020. <http://www. missouribotanicalgarden.org/PlantFinder $>$.

Muchate, N.S., G.C. Nikalje, N.S. Rajurkar, P. Suprasanna, and T.D. Nikam. 2016. Plant salt stress: Adaptive responses, tolerance mechanism and bioengineering for salt tolerance. Bot. Rev. 82:371-406, doi: 10.1007/s12229-0169173-y.

Munns, R. 2002. Comparative physiology of salt and water stress. Plant Cell Environ. 25:239 250, doi: 10.1046/j.0016-8025.2001.00808.x.

Munns, R. 2005. Genes and salt tolerance: Bringing them together. New Phytol. 167:645-663, doi: $10.1111 /$ j.1469-8137.2005.01487.x.

Munns, R. and M. Tester. 2008. Mechanisms of salinity tolerance. Annu. Rev. Plant Biol. 59:651-681, doi: 10.1146/annurev.arplant.59.032607.092911.

Naidoo, G. and Y. Naidoo. 1998. Salt tolerance in Sporobolus virginicus: The importance of ion relations and salt secretion. Flora 193:337-344, doi: 10.1016/S0367-2530(17)30859-9.

Niu, G. and D.S. Rodriguez. 2006. Relative salt tolerance of five herbaceous perennials. HortScience 41:1493-1497, doi: 10.21273/ HORTSCI.41.6.1493.

Niu, G. and R.I. Cabrera. 2010. Growth and physiological responses of landscape plants to saline water irrigation - a review. HortScience 45: 1605-1609, doi: 10.21273/HORTSCI.45.11.1605.

Pawlowicz, I., A. Waśkiewicz, D. Perlikowski, M. Rapacz, D. Ratajczak, and A. Kosmala. 2018. Remodeling of chloroplast proteome under salinity affects salt tolerance of Festuca arundinacea. Photosynth. Res. 137:475-492, doi: 10.1007/s11120-018-0527-7.

Pearen, J.R., M.D. Pahl, M.S. Wolynetz, and R. Hermesh. 1997. Association of salt tolerance at seedling emergence with adult plant performance in slender wheatgrass. Can. J. Plant Sci. 77:81-89, doi: 10.4141/P95-159.

Redmann, R.E. 1972. Plant communities and soils of an eastern North Dakota prairie. Bull. Torrey Bot. Club 99:65-76, doi: 10.2307/2423431.

Rockaway, Inc. 2020. Salt tolerant plants for North Florida. Rockaway, Inc., Jacksonville Beach, FL. 12 Dec. 2020. <www.rockawayinc.com>.

Ruess, R.W., D.D. Uliassi, C.P.H. Mulder, and B.T. Person. 1997. Growth responses of Carex ramenskii to defoliation, salinity, and nitrogen availability: Implications for geese-ecosystem dynamics in western Alaska. Ecoscience 4:170-178, doi: 10.1080/ 11956860.1997.11682392

Schiavon, M., B. Leinauer, M. Serena, R. Sallenave, and B. Maier. 2012. Bermudagrass and seashore paspalum establishment from seed using differing irrigation methods and water qualities. Agron. J. 104:706-714, doi: 10.2134/agronj2011.0390.

Schiavon, M., B. Leinauer, M. Serena, B. Maier, and R. Sallenave. 2014. Plant growth regulator and soil surfactants' effects on saline and deficit irrigation warm-season grasses: I. Turf quality and soil moisture. Crop Sci. 54:2815-2826, doi: 10.2135/cropsci2013.10.0707.

Sun, Y. and A. Palmer. 2018. Responses of ornamental grass and grass-like plants to saline water irrigation. HortTechnology 28:799-806, doi: 10.21273/HORTTECH04159-18.

Sun, Y., G. Niu, and C. Perez. 2015. Relative salt tolerance of seven of Texas Superstar ${ }^{B}$ perennials. HortScience 50:1562-1566, doi: 10.21273/HORTSCI.50.10.1562.

Sun, Y., J. Chen, H. Xing, A. Paudel, G. Niu, and M. Chappell. 2020a. Growth, visual quality, morphological responses of 12 viburnum taxa to saline water irrigation. HortScience 55: 1233-1241, doi: 10.21273/HORTSCI14940-20.

Sun, Y., L. Li, Y. Wang, and X. Dai. 2020b. Morphological and physiological responses of spirea species to saline water irrigation. HortScience 55:888-895, doi: 10.21273/ HORTSCI14861-20

Tada, Y., S. Komatsubara, and T. Kurusu. 2014. Growth and physiological adaptation of whole plants and cultured cells from a halophyte turf grass under salt stress. AoB Plants 6:1-11, doi: 10.1093/aobpla/plu041.

Vitt, D.H., L.C. Glaeser, M. House, and S.P. Kitchen. 2020. Structural and functional responses of Carex aquatilis to increasing sodium concentrations. Wetlands Ecol. Manage. 28:753-763, doi: 10.1007/s11273-020-09746-9.

Wang, Y., Y. Sun, G. Niu, C. Deng, Y. Wang, and J. Gardea-Torresdey. 2019. Growth, gas exchange, and mineral nutrients of ornamental grasses irrigated with saline water. HortScience 54:1840-1846, doi: 10.21273/HORTSCI 13953-19.

Wu, L., X. Guo, and A. Harivandi. 2001. Salt tolerance and salt accumulation of landscape plants irrigated by sprinkler and drip irrigation systems. J. Plant Nutr. 24(9):1473-1490, doi: 10.1081/PLN-100106996. 